\title{
Factors That Matter for Financial Inclusion: Evidence from Sub-Sharan Africa - The Zimbabwe Case
}

\author{
David Mhlanga \\ School of Business and Economics, \\ University of Johannesburg, \\ PO Box 524, Auckland Park, 2006, \\ South Africa
}

DOI: https://doi.org/10.36941/ajis-2021-0152

\section{Abstract}

The study intended to investigate the factors that are important in influencing the financial inclusion of smallholder farming households in Sub-Saharan Africa with a specific focus on Zimbabwe. Motivated by the fact that there is an increase in the evidence of the importance of financial inclusion in fighting poverty and the fact that by merely having a bank account, financial inclusion cannot be guaranteed, the study went further to interrogate factors that influence smallholder farmers to have a transaction account, to borrow and to have insurance. Since the dependent variable of financial inclusion had more than two categories, with three unordered categories, transaction account, savings/credit account, and insurance, the multinomial logistic regression was used to estimate the determinants of financial inclusion from these three categories of the dependent variable. The multinomial logit model results, with insurance as the reference category, indicated that the size of the household, transaction costs, gender and agricultural extension service were the factors influencing the demand for a household to open a transaction account. On the other hand, off-farm income and age of the household were the only two factors significantly influencing households to borrow. Therefore, it is imperative for, the government of Zimbabwe to come up with more policies that encourage farmers to participate in the formal financial market as financial inclusion can help to fight poverty and the general developments of societies.

KeyWords: agricultural sector, factors, financial inclusion, Zimbabwe

\section{Introduction}

Financial inclusion has been recognized as among the important tools for achieving economic growth and poverty reduction (Izquierdo \& Tuesta, 2015). The objective of achieving universal financial access by 2020 buttressed the idea that financial inclusion can indeed help to achieve economic growth and poverty reduction (Mhlanga, 2020a; WBG 2018a). This year 2020 presented a challenge to many countries to improve financial inclusion and achieve their commitments with regard to it (Mhlanga, 202ob; Mhlanga \& Denhere, 2021; WBG 2018a). Issues around financial inclusion are becoming more 
critical especially among international institutions, policymakers, central banks, financial institutions and governments. It is generally believed that private financial institutions are major and critical agents of financial inclusion because of their role in the provision of financial products to the people (Mhlanga, 2020a; Mhlanga et al., 2020). However, the World Bank Group (2018a) (WBG), stated that due to the importance of financial inclusion in lifting people out of the clutches of poverty, it is believed that governments should play critical roles in creating policies that mitigate the problems of market failure (Mhlanga \& Dunga, 2020; Mhlanga \& Garidzirai, 2020; Yakubu et al.,2017; WBG 2018a).

According to the WBG (2018a), access to a transaction account is one of the first steps towards financial inclusion since it gives people the choice to store money as well as sending and receiving. The WBG (2018a), argues that a transaction account is a gateway to other financial services. As a result, the WBG (2018a) is trying everything to ensure that people have access to a transaction account in its, Universal Financial Access 2020 initiative. Demirgüç-Kunt et al. (2008) also argued that access to financial services and products facilitates daily living and planning. With financial access, households and businesses can plan for long term goals and unexpected emergencies. As if not enough, households or individuals with accounts can use other financial services like credit and insurance. Also, this account can be used as a gateway to get loans to start businesses, do investments in education and health, being able to do risk management as well as weathering financial shocks (Demirgüç-Kunt et al., 2008). This can help to improve the overall quality of life of the people.

There is considerable progress in terms of achieving financial inclusion. The WGB (2018a), insinuates that about $\mathbf{1 . 2}$ billion adults worldwide have had access to a bank account since 2011 . Currently, 69 per cent of adults have a bank account. The World Bank believes that moving from access to a bank account to usage is the most important step that needs to be scaled up in countries where 8o per cent or more of households have accounts. Countries like Kenya, Thailand, India, and China have almost 80 per cent of their adults with bank accounts, what needs to be done in these countries is to find ways of scaling access from bank account ownership to full usage of all other services offered by financial institutions. However, it is believed that close to 1.7 billion adults are still unbanked according to the latest Findex data (Izquierdo and Tuesta, 2015; WBG 2018b). According to Raichoudhury (2020), financial inclusion is important and it can act as an all-a critical barometer for all-encompassing growth in all the countries whether developed or developing. The other important point raised by Raichoudhury (2020) was that knowing the direct and indirect link between financial inclusion and socio-economic development is important for policymakers as they can use the information to come up with effective programmes that will help in the expansion of financial inclusion which can lead to a reduction in poverty and inequality. Using India as a case study, the study by Raichoudhury (2020) found out that income level, infrastructure and employment opportunities were the most important determinants of financial inclusion. It was also highlighted that computerised indices can act as an important measure of financial inclusion at the micro-level and over some time.

Research by Kaur and Kapuria (2020) examined the determinants of having access to institutional and non-institutional finance across the female- and male-headed households in rural India. Through successfully using the multinomial logit model the study discovered that femaleheaded households had a lower probability of accessing institutional finance and a higher probability of accessing non-institutional finance compared to their male counterparts. The results also highlighted that the level of education, monthly household consumption expenditure, land size holding, irrigated area and penetration of scheduled commercial banks influences female-headed households in accessing institutional finance. The results by Kaur and Kapuria (2020) also revealed that female-headed households belonging to socially disadvantaged groups have a lower probability of accessing institutional finance. Eldomiaty et al. (2020) also examined the impact of world governance indicators on financial inclusion across the world economies. Through the use of panel data analysis, a fixed generalized linear model, Eldomiaty et al., (2020) discovered that control of corruption, the effectiveness of the government, the stability in politics and voice as well as accountability were the significant variables that influence financial inclusion. Abel et al. (2018) also assessed the determinants of financial inclusion in Zimbabwe. The study discovered that the age of 
an individual, the level of education, financial literacy, the level of income and internet connectivity were positively related to financial inclusion. While documentation is required to open a bank account and distance to the nearest financial institution. Taking from the data gathered and information presented above, the current study will assess the driving factors of financial inclusion among the smallholder farmers in Sub-Saharan Africa with a direct focus on Zimbabwe. The rest document is organised as follows: Section 2 presents the financial participation in Zimbabwe, section 3 is documenting the empirical literature review. The research methodology is represented in section 5. The results of the study are represented in section 5.2. Sections 6 and 7 gives the conclusion of the study and acknowledgements.

\section{Financial Participation in Zimbabwe}

Financial inclusion is viewed as a prime development concern in the world today (Raichoudhury, 2020). Raichoudhury, (2020) defined financial inclusion as:

"a process that makes sure that all members of an economy have no difficulty accessing, avail and use the services provided by the recognized financial system".

The importance of an all-inclusive financial system comes in various ways which include aiding efficient allocation of productive resources, reducing the cost of capital. It can also improve the daily administration of finances and reducing the growth of informal sources of credit (Raichoudhury, 2020).

Financial inclusion in Zimbabwe is viewed as:

"the effective use of a wide range of quality, affordable and accessible financial services, provided fairly and transparently through formal or regulated entities to all Zimbabweans(Mhlanga, 2020a).

Several principles emerge from the definition of financial inclusion which includes the provision of quality financial services to all the citizens. The other principle is that financial services should be accessible to everyone. In Zimbabwe, at the moment it is estimated that almost 76 per cent of Zimbabwean adults are not formally banked which is one of the highest figures the world over (Chivasa \& Simbanegavi, 2016; Mhlanga, 2020a).

Figure one below is showing the position of financial inclusion in Zimbabwe among adults.

Figure 1: The state of Financial Inclusion in Zimbabwe

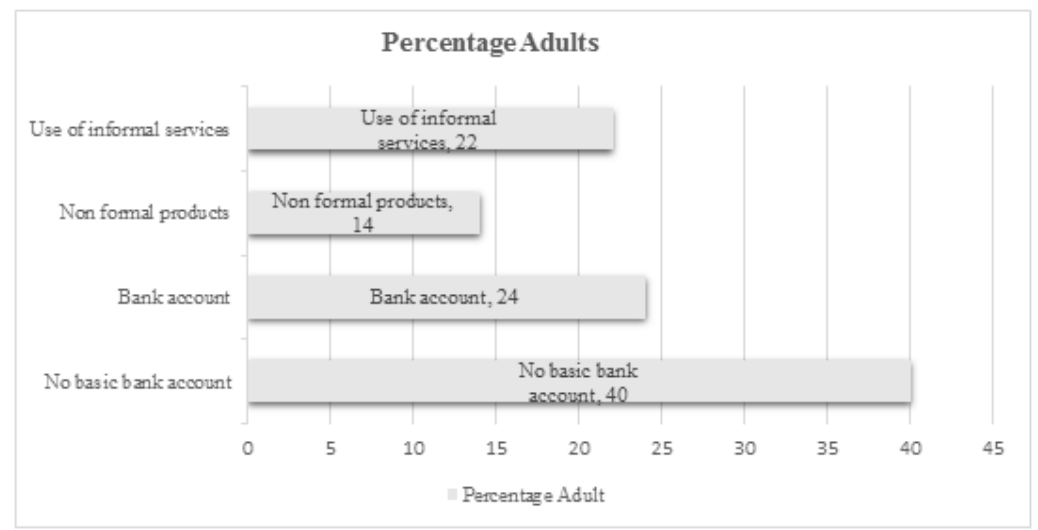

Source: Chivasa \& Simbanegavi, (2016), Zimbabwe National Financial Inclusion Strategy (2016), Mhlanga, (2020a). 
Figure 1 above is showing that 40 per cent of adults in Zimbabwe do not have a bank account, while 22 per cent use informal services and 14 per cent use non-formal products. It was also highlighted that 76 per cent of adults who are not formally, (financially) active in the financial sector, are people living in rural areas. Many of these individuals are in Matebeleland North with almost 6o per cent of adults who are not financially active (Chivasa \& Simbanegavi, 2016; Mhlanga, 2020a). This information is well presented in Figure 2 below which shows financial exclusion by the province in Zimbabwe.

Figure 2: Financial exclusion by the province in Zimbabwe

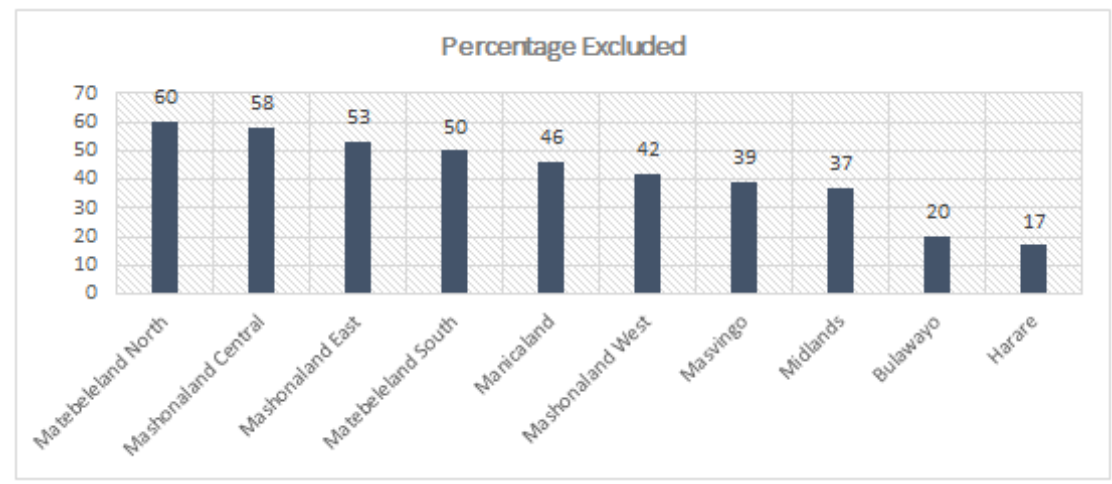

Source: Chivasa \& Simbanegavi, (2016) Zimbabwe National Financial Inclusion Strategy (2016) Mhlanga, (2020a).

As indicated in Figure 2 above; Matebeleland North was the province with the highest number of excluded people followed by Mashonaland Central, Mashonaland East, Matabeleland South and finally the lowest is Harare. As shown in the figure above rural areas are those with the highest number of people who are financially excluded. The major reasons for low levels of inclusion given by Chivasa and Simbanegavi (2016) are poor income levels or low levels of culture/knowledge for saving wealth in other forms like cattle/livestock. The other point that was given is the high level of poverty which is exacerbated by financial illiteracy(Mhlanga, 2020a). Figure 2 also indicates that urban areas are better off concerning financial inclusion compared to rural areas. For instance, Harare and Bulawayo were the two provinces with the lowest financial exclusion of the adult population. The reason for the low levels of financial exclusion is the fact that these are capital cities with many financial institutions and the people in these places are generally financial literate compared to urban areas.

\section{Empirical Literature Review}

There are many theories of financial inclusion that tries to give a picture of the benefits and some of the circumstances that affect or motivate households to participate in the financial market (Chivasa \& Simbanegavi, 2016; Ozili, 2020). Ozili (2020) argued that there are conflicting ideas on the final beneficiary of financial inclusion outcomes. We have studies that insinuate that the ultimate beneficiaries of financial inclusion efforts are the poor while others argue that the ultimate beneficiaries are only women (Bhandari, 2018; Ghosh \& Vinod, 2017; Demirguc-Kunt et al, 2013; Swamy, 2014; Ozili, (2020). The other group of researchers believe that the economy and the financial system benefit more from financial inclusion outcomes (Mehrotra \& Yetman, 2015; Ozili, 2018). Ozili(2020) also argued that despite women and poor people, the youth, the elderly, institutionalized 
and ill people, the disabled people and those who were previously expelled from the financial sector are some of the groups ignored who can benefit more from financial inclusion.

Akileng et al. (2018) examined financial literacy and financial innovation with a deep objective to understand if these variables improve financial inclusion among households in Uganda. Using the survey data and regression analysis, the study found out that financial innovation and financial literacy are the best determinants of financial inclusion among households compared to variables like cost of the transactions, age and location. The conclusion that was given by Akileng et al. (2018) was that when households are financial literate, they can make informed decisions about the financial products and services. In another study, Okoroafor et al. (2018) assessed the determinants of financial inclusion in Nigeria using time series data from 1990 to 2016. The results that the researcher found were completely different from those found by Akileng et al. (2018). Okoroafor et al. (2018) discovered that the higher GDP of a nation improves financial inclusion in the financial system. It has been also discovered that the increase in broad money in circulation in a nation improves financial inclusion (Okoroafor et al., 2018). The other independent variable that was found was the usage of the internet, the more people make use of it, the more financial inclusion improves. The other conclusion by Okoroafor et al. (2018) was that internet use is critical because it helps to reduce the cost of transactions through the use of mobile money and automated teller machines. The use of mobile money was also viewed as a way that can help to improve the delivery of mobile money in remote areas in the nation as it allowed home banking to be a reality since these mobile money accounts can be operated also by illiterate people.

Amoah et al. (2020) also went a step to examine the motivating factors for use of mobile money in Ghana. Using the logistic regression, the study discovered that the phone service recharge, the education level and income level of the household are the key determinants of mobile money use in Ghana. The study also found out that the use of mobile to access social and economic services can go a long way to promote financial inclusion and financial empowerment. Dar and Ahmed (2020) also sought to understand the determinants of financial inclusion and the determinants of barriers to financial inclusion in India. The study also sought to determine the determinants of informal financial activities in India. The study discovered that gender, age, education and income were the significant factors in influencing financial inclusion. These factors were also seen to be critical in improving informal saving and borrowing.

Ali et al. (2020) also sought to assess the determinants of Islamic financial inclusion in Indonesia. Through the use of the analytic network process to get expert opinions from academics and practitioners the study found out that financial inclusion was influenced by demand-side and supply-side factors. On the demand side, Islamic financial inclusion was influenced by financial literacy, religious commitment, socioeconomic factor and social influence while the supply side of Islamic financial inclusion was influenced by the level of importance of human capital, the nature of products and services, the infrastructure as well as the policies and regulation. All these factors were viewed as important factors in creating an enabling environment for policymakers to strengthen Islamic financial inclusion in Indonesia (Ali et al., 2020).

\section{Research Methodology and Data}

This research used primary data that was collected using a structured questionnaire. The questionnaire went through ethical clearance at North-West University through the North-West University Education, Management and Economic Sciences, Law, Theology, Engineering and Natural Sciences Research Ethics Committee (NWU-EMELTEN-REC) under the clearance number NWUo0354-19-2A. Data sources were household heads both male and female who were into farming during the survey. In Zimbabwe, these farmers are commonly referred to as $A_{1}$ and $A_{2}$ farmers. $A_{1}$ model is generally referred to as communal subsistence farming which comes as a village or selfcontained model variant (Goebel, 2005). On the other hand, the A2 farming model comes in as smallscale, medium, and large scale farming models (Chigumira, 2010). For purposes of this study on the 
A2 farming model, only small-scale farmers have been part of it. The study used a structured questionnaire to collect the data following the works of Malhotra (2010); Meyer (2018) and Matsekoleng and Mapotse (2018). Through the use of non-probability convenient sampling, the study successfully analyzed the data collected from 405 smallholder farmers in 2019.

\subsection{Multinomial Logit Model Data Analysis}

The study investigated the factors that influences households to choose the different services provided by financial institutions which include account ownership, savings account, or credit account and insurance. As a result, the dependent variable did not assume one category, it had more than one category which motivated the adoption of the multinomial logistic regression. The dependent variable was described as financial inclusion with three categories. The multinomial logistic regression was used to investigate the determinants of financial inclusion among smallholder farmers. As articulated by Madhu et al. (2014); Hanushek and Jackson (2013) and Mhlanga (2020a) the multinomial is also known as polytomous logistic regression, a form of binomial logistic regression used in circumstances where the dependent variable assumes more than two mostly unordered categories. The multinomial logistic regression uses the maximum likelihood estimation just like the logistic regression to evaluate the probability of a categorical membership.

The study followed the works of Greene (2003). In this case the $\mathrm{i}^{\mathrm{th}}$ respondent faced with $\mathrm{j}$ choices, the utility choice $\mathrm{j}$ was expressed as: $U_{i j}=Z_{i j} \beta+\varepsilon_{i j} \quad$ (1)

After assuming that the household will come with a choice $\mathrm{j}$, then $U_{i j}$ was the maximum utility that the respondent could obtain from the $\mathrm{j}$ choices The final result was the statistical model which was derived by the probability that choice $\mathrm{j}$ is made, which is expressed as: $\operatorname{Pr}\left(U_{i j}>U_{i k}\right)$ for all other $\mathrm{k} \neq \mathrm{j} \quad$ (2)

In equation 2, $U_{i j}$ is the utility of the $i^{t h}$ household, from financial service $\mathrm{j}$ while $U_{i k}$ is the utility to the $i^{\text {th }}$ household from financial service k. Brown and Brown (2006) stated that the choice of the household is the optimal allocation of the asset endowment if the $i^{\text {th }}$ respondent's utility is maximised as a result of the selected livelihood strategy.

As a result, the decision of the $i^{\text {th }}$ household can ultimately be modelled through maximizing the expected utility by selecting the $j^{\text {th }}$ financial service among $\mathrm{j}$ discrete financial services as shown in the equation: $\max _{\mathrm{j}}=E\left(U_{i j}\right)=f_{j}\left(x_{i}\right)+\varepsilon_{i j} ; j=0 \ldots J \quad$ (3)

The outcome variable has J categories, the $j^{\text {th }}$ livelihood strategy that the $i^{\text {th }}$ the household will choose to maximize utility could take the value of 1 if the $i^{\text {th }}$ household choose $j^{\text {th }}$ financial service and o otherwise. Therefore, the probability that a household with characteristics $\mathrm{x}$ chooses the financial service $\mathrm{j}, P_{i j}$ can be modelled as: $P_{i j}=\frac{\exp \left(X_{i}^{\prime} \beta_{j}\right)}{\sum_{j=0}^{J} \exp \left(X_{i}^{\prime} \beta_{j}\right)}, j=0 \ldots 3$ (4)

Applying the requirement that $\sum_{j=0}^{J} P_{i j}=1$ for any $i$. Where $P_{i j}=$ probability representing the $i^{\text {th }}$ respondents' chance of falling into category $\mathrm{j}$. $\mathrm{X}=$ predictors of response probabilities. $\beta_{j}=$ covariate effects specific to the $j^{\text {th }}$ response category with the first category as the reference. To remove an indeterminacy in the model, appropriate normalization that is to be carried out should assume that this arises because probability sum to 1 , so only J parameter vectors are needed to determine the $j+1$ probability, so that, $\exp \left(X_{i}^{\prime} \beta_{j}\right)=1$ (Greene, 2003; Mapfumo, 2015). This will imply that the generalization equation (4) above is equivalent to: $\operatorname{Pr}\left(y_{i}=j / X_{i}\right)=P_{i j}=\frac{\exp \left(X_{i}^{\prime} \beta_{j}\right)}{1+\sum_{j=1}^{J} \exp \left(X_{i}^{\prime} \beta_{j}\right)}$, for $j=0,2 \ldots J$ and $\operatorname{Pr}\left(Y_{i}=j\right)=\frac{e^{\beta_{j} x_{i}}}{\sum_{K=0}^{J} e^{\beta_{k} x_{i}}}, j=$ $0,1 \ldots J \quad(5)$

Where, $\beta_{i}=$ a vector of coefficients on each of the household attributes, $\beta_{k}=$ the vector of coefficients of the base alternative and $j$ denotes the specific one of the $j+1$ possible livelihood choices.

The model was used to highlight key household attributes like education and gender that differentiate the access to various financial services from financial institutions by households. The objective was to investigate the determinants that influences households to choose among the different financial services in a given period. A rational household head chooses among the three 
mutually exclusive financial services to derive maximum utility. In this case, the three services include transaction account, credit account and insurance. The table below is showing the independent variables used in the study.

Table 1: Independent variables

\begin{tabular}{|l|l|c|}
\hline \multicolumn{1}{|c|}{ Variable } & \multicolumn{1}{c|}{ Unit } & Expected Sign \\
\hline Education level & Number & + \\
\hline Gender of household head & Male =1, Female = o & $+/-$ \\
\hline Age of household head & Number & $+/-$ \\
\hline Household size & Number & $+/-$ \\
\hline Off-farm income & Unites States Dollars & $+/-$ \\
\hline Land Size & Hectare & + \\
\hline Informal Credit Participation & Dummy Variable : Participation = 1 Non-Participation =o & - \\
\hline Agricultural Extension Service & Dummy Variable : Participation = 1 Non-Participation $=0$ & $+/-$ \\
\hline Transaction cost & Cost of withdrawal, Opening account & $+/-$ \\
\hline Distance from the financial institution & Distance in kilometres & $+/-$ \\
\hline Financial literacy & Knowledge about financial products & $+/-$ \\
\hline Marital status & Married=1,Divorced=2,Widowed=3 & $+/-$ \\
\hline
\end{tabular}

Source: Mhlanga (2020a)

The table above is showing all the independent variables used in the study with the final model being specified in equation 6 as IFI $=\beta_{O}+\beta_{1} E D U C L+\beta_{2} G E N D H H+\beta_{3} A G E H H+\beta_{4} H S I Z E+\beta_{5} O F F-$ FARMI $+\beta_{6}$ LANDSIZE $+\beta_{7}$ INFINPART $+\beta_{8}$ AGREXTSERVI $+\beta_{9}$ DISTANCE $+\beta_{10}$ TRANSCOSTS + $\beta_{11}$ FINLIT $+\beta_{12} M T+\varepsilon$

4.2 Results and discussion on the determinants of financial inclusion through the multinomial logistic regression model smallholder farmers

Demographic Information Related to the Sample Size

Table 2: Gender composition of the Sample

\begin{tabular}{lcc}
\hline \multicolumn{3}{c}{ Gender composition of the households in the sample } \\
\hline Female & 142 & $35 \%$ \\
Males & 263 & $65 \%$ \\
Total & 405 & $100 \%$ \\
\hline
\end{tabular}

Source: Author's Calculations

Table 2 above indicates that from a total of 405 households who successfully participated in the survey, 142 translating to 35 per cent were females while 263 translating to 65 per cent were males. Table 3 is summarizing the multinomial logistic regression results.

The following table is showing the results from the multinomial logistic regression. 
Table 3: Multinomial logistic regression results

\begin{tabular}{|c|c|c|c|c|c|c|c|c|}
\hline Variable & $\mathrm{B}$ & Std. Error & Wald & Df & Sig. & $\operatorname{Exp}(B)$ & \multicolumn{2}{|c|}{ 95\% Confidence Interval $\operatorname{Exp}(B)$} \\
\hline \multicolumn{2}{|l|}{ Transaction Account } & & & & & & Lower Bound & Upper Bound \\
\hline Intercept & .509 & 1.057 & .231 & 1 & .631 & & & \\
\hline Household size & .378 & .115 & 10.859 & 1 & $.001^{* * *}$ & 1.459 & 1.166 & 1.827 \\
\hline Transction costs & .082 & .036 & 5.229 & 1 & $.022^{* *}$ & 1.085 & 1.012 & 1.165 \\
\hline Age & -.029 & .016 & 3.114 & 1 & $.078^{*}$ & .972 & .941 & 1.003 \\
\hline Distance & -.089 & .100 & .791 & 1 & .374 & .915 & .753 & 1.113 \\
\hline Off-farm income & -.002 & .001 & 1.986 & 1 & .159 & .998 & .996 & 1.001 \\
\hline Gender & .378 & .370 & 1.044 & 1 & .307 & 1.460 & .707 & 3.014 \\
\hline Agricultural extension service(1) & .845 & .481 & 3.086 & 1 & $.079^{*}$ & 2.328 & .907 & $5 \cdot 974$ \\
\hline Marital status (1) & -.370 & .355 & 1.086 & 1 & .297 & .690 & .344 & 1.386 \\
\hline Financial literacy & -.211 & .355 & .351 & 1 & .553 & .810 & .404 & 1.625 \\
\hline \multicolumn{3}{|l|}{ Credit Account } & & & & & & \\
\hline Intercept & -.903 & 1.029 & .770 & 1 & .380 & & & \\
\hline Household size & .108 & .112 & .933 & 1 & .334 & 1.114 & .895 & 1.388 \\
\hline Transaction costs & -.030 & .035 & .742 & 1 & .389 & .970 & .905 & 1.040 \\
\hline Age & .026 & .016 & 2.719 & 1 & $.099^{*}$ & 1.026 & .995 & 1.058 \\
\hline Distance & .003 & .097 & .001 & 1 & .975 & 1.003 & .829 & 1.213 \\
\hline Off-farm income & .003 & .001 & 6.657 & 1 & $.010^{* *}$ & 1.003 & 1.001 & 1.005 \\
\hline Gender & .335 & .362 & .857 & 1 & .355 & 1.398 & .688 & 2.842 \\
\hline Agricultural (1) & .085 & .454 & .035 & 1 & .852 & 1.088 & .447 & 2.652 \\
\hline Marital Status (1) & -.198 & .346 & .327 & 1 & .568 & .820 & .416 & 1.617 \\
\hline Financial Literacy (1) & -.228 & .347 & .431 & 1 & .512 & .796 & .403 & 1.573 \\
\hline \multicolumn{3}{|c|}{ Reference Category Insurance } & & & & & & \\
\hline
\end{tabular}

Model Fitting Information -2 Log Likelihood Intercept Only (709.498), Final (617.880) Chi-Square (91.619) df (18) Sig. (o.ooo) Goodness-of-FitChi-SquarePearson578.343 Deviance 570.793 df(372) Sig. (o.ooo) Pseudo R-Square, Cox and Snell.202, Nagelkerke.238 McFadden.119(significant at 1 percent $^{* * *}, 5$ percent $^{* *}$, 10 percent ${ }^{*}$ )

\section{Source: Mhlanga (2020a)}

The model went through the multicollinearity test and the Pearson correlation coefficient results highlighted that there was no multicollinearity. In relation to multicollinearity, all the independent variables had correlation coefficient values were less than 0.8 and -0.8 indicating that the variables had no problem of multicollinearity. The final results from the multinomial logistic regression indicated that the size of the household, transaction costs, gender and agricultural extension were the significant factors influencing household to have a transaction account taking insurance as a reference category. Household size was significant at a 1 per cent level of significance with a (P-value, .oo1). The results also revealed that household size had a positive influence on the probability of a household having a transaction account with an odds ratio of 1.459. The meaning of this is that an increase in the size of the household by a unit will influence the probability of demand for a transaction account by 1.459. The positive impact of household size on the demand for a transaction account was in line with the a priori expectation in the study. There is a possibility that the size of the household can influence a household to have a traction account positively or negatively. The results were supported by various scholars like Chandio et al. (2017) and Evans (2016). Concerning smallholder farming household with more members tend to have more output as a result of more labour. This can also increase the income from the sales of the output encouraging the household to have a transaction account.

The results also revealed that transaction costs were a significant variable in influencing households to have a transaction account. Transaction costs were significant at a 5 per cent level of significance with a (P-value, .022) and odds ratio of 1.085. Transaction costs had a positive influence 
on households to have a transaction account. This means that the lower the transaction costs the higher the probability of the households having a transaction account. The a priori expectation was that transaction costs can motivate or demotivate households to demand transaction account. When transaction costs are high the demand for a transaction account declines and the opposite is true. The results were supported by many authors like Oyelami et al. (2017) and Kodongo (2018) who indicated that high transaction costs can discourage households to demand financial products and services provided by financial institutions, while low transaction costs can encourage the use of them.

The other important finding from the results was that age of the household was among the significant factors in influencing demand for a transaction account. The variable was significant at a 10 per cent level of significance with a (P-value, .078) and odds ratio of 0.972 . The variable had a negative influence on the demand for a transaction account. The meaning of the results was that when the age of the household increases by a unit, the probability demand for a transaction account declines by approximately 0.972 . The variable age can have a positive or negative influence on the demand for financial products and services. Positively as the age of the people improves them. They tend to understand the importance of financial products and services more compared to when they are young, and this will lead them to use more of these services and products up to a point where the demand starts to decline with old age. This was supported by several studies like Sanderson et al. (2018); Masiyandima et al. (2017); Kodongo (2018); and Evans (2016). Sanderson et al. (2018) revealed that age can have a positive influence on financial inclusion up to a certain age beyond which it will become negative. This will have to mean the demand for financial products increases up to a certain point beyond which it will decline.

Moreover, the results also indicated that agricultural extension service was significant with a positive significant influence on demand for a transaction account. The variable was significant at a 1o per cent level of significance with a significant (P-value, o.o79.). The results implied that households who are recipients of agricultural extension services have more chances of having a transaction account compared to households who did not participate in agricultural extension services. Participation made it possible for households to receive high yields which in effect influences the desire to use financial products and services. These results were supported by the author like Akudugu (2013) and Yakubu et al. (2017) who found out that agricultural extension service is critical in influencing households to use financial products. The study also sought to investigate the factors that influence households to demand credit. The results highlighted that transaction costs, marital status and financial literacy were the variables with a negative influence on financial inclusion while household size, age of the household head, distance to the nearest financial access point, offfarm income, gender and agricultural extension service were the variable with a positive influence on financial inclusion in terms of demand for credit by the households. Finally, the results indicated that off-farm income and age of the household were the only two significant variables in influencing households to borrow.

The variable age had a positive influence on the demand for a credit account and it was significant at 10 per cent with a (P-value,o.099) and an odds ratio of 1.026. The variable age had a negative influence on demand for a transaction account while on the demand for credit the variable had a positive influence. This is in line with arguments given by various scholars like Nguyen (2007) and Buckley (1997). The scholars argued that the age of the household can have a negative or positive influence on financial inclusion. Nguyen (2007) argued that at a young age demand for credit increases especially among the youth due to little wealth. The argument given was that for the youth to increase wealth, they tend to borrow more up to a point where the demand declines (Nguyen, 2007; Buckley, 1997). In this way, age increases the probability of demand for credit among the smallholder farmers up to a certain point beyond which the demand will decline.

The results went on to show that off-farm income was significant at a 1 per cent level of significance with a positive significant influence on the probability of households to borrow or to have credit. The variable had an odds ratio of 1.003. The meaning of these results was that a unit change in the income of a household is associated with a 1.003 increase in the probability of demand 
for credit. This result was supported by several scholars who found out that the amount of income an individual has, influences the individual to participate in the formal financial institution (Musabanganji et al., 2015; Chandio et al., 2017; Kodongo, 2018). This result concurred with the result found using the index of financial inclusion and the logit model that off-farm income positively encourages households to participate more in the formal financial institution.

\section{Conclusion and Policy Recommendations}

The purpose of the study was to assess the driving factors of financial inclusion among the smallholder farmers in Sub-Saharan Africa with a direct focus on Zimbabwe. Using the multinomial logit model results, with insurance as the reference category, the results indicated that the size of the household, transaction costs, gender and agricultural extension service were the factors influencing the demand for a household to open a transaction account. On the other hand, off-farm income and age of the household were the only two factors significantly influencing households to borrow. The results highlighted that agricultural extension services are important in influencing households to have a bank account, this shows that households who receive financial education through various extension services stand a better chance of opening a bank account. Transaction costs were also identified to affect the households participating informal financial markets. It is therefore important to ensure that financial services providers review transaction costs and charges periodically because it is one of the variables that can prevent households from using financial services. Also, the government needs to scale up the extension services to the farmers as they equip them with important information that can help them to be able to participate in the financial sector. In short, the government of Zimbabwe should come up with more policies that encourage farmers to participate in the formal financial market as financial inclusion can help to fight poverty and the general development of societies.

\section{Acknowledgements}

We would like to extend our appreciation to Northwest University for the support the administrative resources required for the successful completion of this study. Also, the government of Zimbabwe and the Ministry of Lands, Agriculture, Water, Climate and Rural Resettlement for providing clearance for this study to be undertaken.

\section{References}

Abel, S., Mutandwa, L., \& le Roux, P. (2018). International Journal of Economics and Financial Issues A Review of Determinants of Financial Inclusion. International Journal of Economics and Financial Issues, 8(3), 1-8. http:www.econjournals.com

Akileng, G., Lawino, G. M., \& Nzibonera, E. (2018). Evaluation of determinants of financial inclusion in Uganda. In Journal of Applied Finance \& Banking (Vol. 8, Issue 4). online) Scienpress Ltd.

Akudugu, M. A. 2013. The determinants of financial inclusion in Western Africa: Insights from Ghana. Research Journal of Finance and Accounting, 4, 1-9.

Ali, M. M., Devi, A., Furqani, H., \& Hamzah, H. (2020). Islamic financial inclusion determinants in Indonesia: an ANP approach. International Journal of Islamic and Middle Eastern Finance and Management, 13(4), 727747. https://doi.org/10.1108/IMEFM-01-2019-0007

Amoah, A., Korle, K., \& Asiama, R. K. (2020). Mobile money as a financial inclusion instrument: what are the determinants? International Journal of Social Economics, 47(10), 1283-1297. https://doi.org/10.1108/IJSE-052020-0271

Bhandari, B. S. (2018). Life Insurance-Social Security \& Financial Inclusion. Bimaquest, 18(2)

Brown, D. R. \& Brown, D. R. 2006. Livelihood strategies in the rural Kenyan highlands, Cornell University.

Buckley, G. 1997. Microfinance in Africa: Is it either the problem or the solution? World Development, 25, $1081-1094$.

Chandio, A. A., Jiang, Y., WEI, F., Rehman, A. \& LIU, D. 2017. Famers' access to credit: Does collateral matter or cash flow matter? -Evidence from Sindh, Pakistan. Cogent Economics \& Finance, 5, 1369383. 
Chigumira, E. 2010b. My Land, My Resource: Assessment of the Impact of the Fast Track Land Reform Programme on the Natural Environment, Kadoma District, Zimbabwe.

Chivasa, S., \& Simbanegavi, P. (2016). Financial Inclusion In Zimbabwe Post Hyper Inflationary Period: Barriers And Effects On Societal Livelihoods, A Qualitative Approach. A Case Of Matebeleland North. Journal of Sustainable Development in Africa, 18(1).

Dar, A. B., \& Ahmed, F. (2020). Financial inclusion determinants and impediments in India: insights from the global financial inclusion index. Journal of Financial Economic Policy. https://doi.org/10.1108/JFEP-11-2019-0227

Demirguc-Kunt, A. \& Levine, R. 2008. Finance, financial sector policies, and long-run growth, The World Bank.

Demirgüç-Kunt, A., \& Klapper, L. (2013). Measuring financial inclusion: Explaining variation in the use of financial services across and within countries. Brookings Papers on Economic Activity, 2013(1), 279-340.

Demirgüç-Kunt, A., Honohan, P. \& Beck, T. 20o8. Finance for all? Policies and Pitfalls in Expanding Access, World bank.

Eldomiaty, T., Hammam, R., \& el Bakry, R. (2020). Institutional determinants of financial inclusion: evidence from world economies. International Journal of Development Issues, 19(2), 217-228. https://doi.org/10.1108/IJDIo8-2019-0147

Evans, O. 2016. Determinants of Financial Inclusion in Africa: A Dynamic Panel Data Approach.

Ghosh, S., \& Vinod, D. (2017). What constrains financial inclusion for women? Evidence from Indian microdata. World Development, 92, 6o-81.

Goebel, A. 2005. Gender and land reform: the Zimbabwe experience, McGill-Queen's Press-MQUP.

Greene, W. H. 2003. Econometric analysis, Pearson Education India.

Hanushek, E. A. \& Jackson, J. E. 2013. Statistical methods for social scientists, Academic Press.

Izquierdo, N. C. \& Tuesta, D. 2015. Factors that matter for financial inclusion: Evidence from Peru. Aestimatio: The IEB International Journal of Finance, 10-31.

Kaur, S., \& Kapuria, C. (2020). Determinants of financial inclusion in rural India: does gender matter? International Journal of Social Economics, 47(6), 747-767. https://doi.org/10.1108/IJSE-07-2019-0439

Kodongo, O. 2018. Financial Regulations, Financial Literacy, and Financial Inclusion: Insights from Kenya. Emerging Markets Finance and Trade, 54, 2851-2873.

Madhu, B., Ashok, N. \& Balasubramanian, S. 2014. A multinomial logistic regression analysis to study the influence of residence and socioeconomic status on breast cancer incidences in southern Karnataka. Int. J. Math. Stat. Invention, 2, 01-8.

Malhotra, N. K. 2010. Marketing research: An applied orientation (Vol. 834). New Jersey: Pearson Education.

Mapfumo, A. 2015. Livelihood strategies and food security for resettled smallholder tobacco and non-tobacco farmers: the case of Manicaland Province in Zimbabwe. The University of Fort Hare.

Mehrotra, A. N., \& Yetman, J. (2015). Financial inclusion issues for central banks. BIS Quarterly Review of March.

Meyer, N. 2018. South African female entrepreneurs' intention to remain in business. North-West University.

Mhlanga, D. (2020a). Financial inclusion and poverty reduction: Evidence from small scale agricultural sector in Manicaland Province of Zimbabwe. Available online: http://repository.nwu.ac.za/handle/10394/34615.

Mhlanga, D. (2020b). Industry 4.0 in Finance: The Impact of Artificial Intelligence (AI) on Digital Financial Inclusion. International Journal of Financial Studies, 8(3), 45. https://doi.org/10.3390/ijfs8o30045

Mhlanga, D., \& Denhere, V. (2021). Determinants of Financial Inclusion in Southern Africa. Studia Universitatis Babes-Bolyai Oeconomica, 65(3), 39-52. https://doi.org/10.2478/subboec-2020-0014

Mhlanga, D., \& Dunga, S. H. (2020). Measuring Financial Inclusion And Its Determinants Among The Smallholder Farmers In Zimbabwe: An Empirical Study. Eurasian Journal of Business and Management, 8(3), $266-281$. https://doi.org/10.15604/ejbm.2020.08.03.008

Mhlanga, D., \& Garidzirai, R. (2020). Energy Demand And Race Explained In South Africa: A Case Of Electricity. Eurasian Journal of Business and Management, 8(3), 191-204. https://doi.org/10.15604/ejbm.2020.08.03.003

Mhlanga, D., Henry Dunga, S., \& Moloi, T. (2020). Financial Inclusion And Poverty Alleviation Among Smallholder Farmers In Zimbabwe. Eurasian Journal of Economics and Finance, 8(3), $168-182$. https://doi.org/10.15604/ejef.2020.08.03.004

MOHAN, R. Economic Growth, Financial Deepening and Financial Inclusion, Address at the Annual Bankers' Conference 2006, Hyderabad on November 3. Migrant Worker Remittances, Micro-finance and the Informal Economy: Prospects and Issues, Working Paper No. 21, Social Finance Unit, International Labour Office, 2006. Citeseer.

Nguyen, C. H. 2007. Determinants of credit participation and its impact on household consumption: Evidence from rural Vietnam. 
Okoroafor, D. O. K., Adeniji, S., David, O. O. K., Oluseyi, A. S., \& Emmanuel, A. (2018). Empirical Analysis of the Determinants of Financial Inclusion in Nigeria: 1990-2016. Journal of Finance and Economics, 6(1), 19-25. https://doi.org/10.12691/jfe-6-1-3

Oyelami, L. O., SAIBU, O. M. \& ADEKUNLE, B. S. 2017. Determinants of Financial Inclusion in Sub-Sahara African Countries. Covenant Journal of Business and Social Sciences, 8.

Ozili, P. K. (2018). Impact of digital finance on financial inclusion and stability. Borsa Istanbul Review, 18(4), 329340.

Ozili, P. K. (2020). Theories of Financial Inclusion. SSRN Electronic Journal. https://doi.org/10.2139/ssrn.3526548

Raichoudhury, A. (2020). Major Determinants of Financial Inclusion: State-Level Evidence from India. Vision: The Journal of Business Perspective, 24(2), 151-159. https://doi.org/10.1177/0972262920923882

Sanderson, A., Mutandwa, L. \& Le Roux, P. 2018. A Review of Determinants of Financial Inclusion. International Journal of Economics and Financial Issues, 8, 1.

Swamy, V. (2014). Financial inclusion, gender dimension, and economic impact on poor households. World Development, 56, 1-15.

WBG, W. B. G. 2018a. Atlas of Sustainable Development Goals from World Development Indicators. Washington DC International Bank for Reconstruction and Development / The World Bank $1818 \mathrm{H}$ Street NW, Washington, DC 20433: World Bank.

WBG, W. B. G. 2018b. UFA2020 Overview: Universal Financial Access by 2020. October 1, 2018, ed. Headquarters The World Bank 1818 H Street, NW Washington, DC 20433 USA Tel: (202) 473-10oo: World Bank Group.

Yakubu, I., Dinye, R., Buor, D. \& Iddrisu, W. A. 2017. Determining and Forecasting Financial Inclusion in Northern Ghana Using Discriminant Analysis. International Research Journal of Finance and Economics.

Zimbabwe National Financial Inclusion Strategy ZINFIS, R. B. O. Z. 2016. Zimbabwe National Financial Inclusion Strategy 2016-2020. In: ZIMBABWE, R. B. O. (ed.). Harare, Zimbabwe: Reserve Bank of Zimbabwe. 